\title{
A Review on Various Analytical Methodologies for Etoricoxib
}

\author{
M. S. Prajapati*, D. B. Yamgar, M. N. Desale, B. Fegade
}

Gahlot Institute of pharmacy, Koparkhairane, Navi-Mumbai, University of Mumbai, India

* Corresponding Author email:
maleshprajapati1@gmail.com

Article History

Received: 19 July 2021

Revised: 07 November 2021

Accepted: 08 December 2021

Published: 23 December 2021

Student(s)

- Malesh Shyamkawal Prajapati

- Dilip Bhagwan Yamgar

- Mayur Narayan Desale

Academic Year: 2020-2021

Course Level: Master

Course Name: M.Pharm. (QA)

Course year: $2^{\text {nd }}$ Year

$\operatorname{Mentor}(s)$

- Dr. Bharti Fegade

\begin{abstract}
Etoricoxib belongs to the class of highly selective COX-2 inhibitor NSAIDs. It is mostly used for the treatment of pain, arthritic conditions including rheumatoid arthritis and osteoarthritis. The current study focuses primarily on analytical and bioanalytical method development methodologies, as well as numerous methods established for the estimation of etoricoxib, whether in pharmaceutical dose form or in bulk. Analytical procedures are critical for determining compositions, as they allow us to obtain both qualitative and quantitative results utilising advanced analytical tools. The analytical method for Etoricoxib may be chromatographic, electrochemical, spectral or hyphenated. These methods aid in the comprehension of critical process parameters as well as the minimization of their impact on precision and accuracy. Analytical method development is required to sustain high commercial product quality standards and to meet regulatory requirements. Following the reference, regulatory organisations in several nations have established standards and procedures for providing approval, authentication, and registration. Bioanalytical methods are designed to quantify the concentration of drug, metabolite, or typical biomarkers from various biological fluids including serum, urine, saliva and tissue extracts.
\end{abstract}

Keywords: Etoricoxib, Analytical, HPLC

\section{Introduction}

NSAIDs have the mechanism of action by inhibition of the prostanoid biosynthesis. It has been prescribed in the management of pain, inflammation and fever. Prostanoid is the lipid mediator which helps in the pathologic and physiologic processes. The prostanoids are synthesized from arachidonic acids and secreted from phospholipid membranes in presence of enzyme phospholipase. It is then converted into the PGG/H (Prostaglandin) synthase into the PG-G2, further, it is converted into the unstable endoperoxide. The end products like prostanoids including PGE2, PGF2 $\alpha$, PGD2 and prostacyclin, these molecules interrupt cellular response and the pathophysiological process like inflammatory reaction, homeostasis, thrombosis and hemodynamic. The isoforms of the PGH-synthase are Cyclooxygenase i.e. COX-1 and 2 which are also called PGHS-1 and PGHS-2. PGHS-1 (COX-1) is expressed in various cells including mammalian, endothelium gastrointestinal mucosa and endothelium. COX-2 is characterized by its active role in 
inflammatory processes and it induces the process of inflammation stimulation. It is associated with pain. NSAID acts by inhibiting the action of COX enzymes and thereby helpful in the reduction of synthesis of pro-inflammatory prostaglandin. Generally, non-selective NSAIDs can inhibit both COX enzymes [1]. Selective COX-2 inhibitors are the subclass of the NSAIDs which is used in the management of pain in Rheumatoid arthritis and osteoarthritis. When compared to the COX-2 inhibitors rofecoxib, valdecoxib, and celecoxib, etoricoxib has a higher selectivity for COX-2 over COX-1 [2,3]. Etoricoxib binds to COX2 in a reversible, noncovalent manner with a 1:1 stoichiometric ratio. In vitro, etoricoxib interfered significantly less with the cardioprotective COX-1-mediated antiplatelet activity of low-dose aspirin than other NSAIDs such as rofecoxib, valdecoxib, celecoxib, and ibuprofen (in ascending order of aspirin antagonism), indicating that etoricoxib has a lower affinity for COX-1 [4].

\subsection{Physicochemical Properties}

Its chemical name is 5-chloro-2-[6-methyl pyridin-3-yl]-3-[4-methylsulfonylphenyl] pyridine. The structure of Etoricoxib has presented in figure 1.Colour of etoricoxib is off-white and the texture is crystalline and it is not soluble in water and a freely soluble aqueous solution of alkali [5]. pKa value is 4.5, absorption maximum $238 \mathrm{~nm} / 280 \mathrm{~nm} \&$ melting point $135-138^{\circ} \mathrm{C}$.

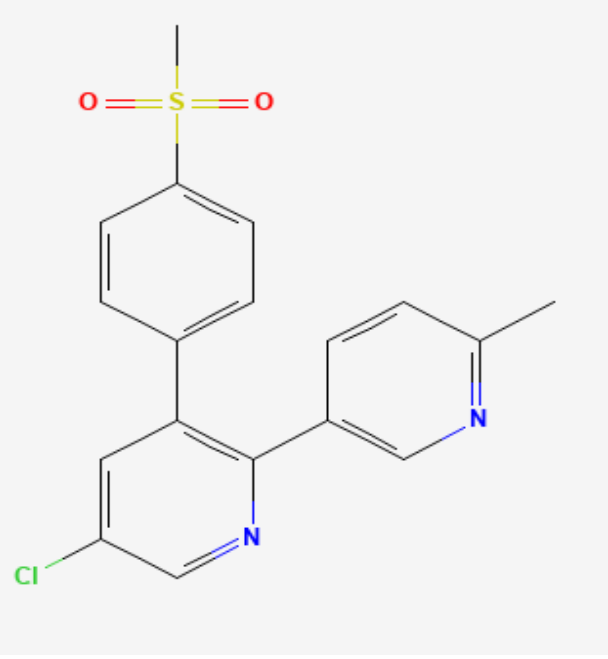

Figure 1: Chemical structure of Etoricoxib

\subsection{Pharmacokinetic properties}

A study has been done on the absorption of the etoricoxib on the single oral doses of the 5, 10, 20, 40 and $120 \mathrm{mg}$. Pharmacokinetics were found to be linear regardless of the formulation [6] Oral etoricoxib is quickly and fully absorbed in healthy volunteers. It has up to 100 percent absolute bioavailability and achieves $\mathrm{C}_{\max }$ after around 1 hour. Following a high-fat meal, absorption is slowed but not reduced, indicating that Etoricoxib can be provided without regard to diet. Etoricoxib has pharmacokinetics that is linear at doses at least 2-fold higher than the maximum clinical dose $(120 \mathrm{mg})$. The study has been reported that, at a steady-state, the dose which is given intravenously showed the average volume of distribution. It was reported that cytochrome P450 (CYP) 3A4 is essential for the highest amount of (40-90\%) of etoricoxib metabolism but other CYP also responsible for the metabolism which includes CYP2D6, CYP2C9, CYP1A2 and CYP2C19 [7]. From intravenous $25 \mathrm{mg}$, etoricoxib was found to be eliminated from plasma in a biphasic fashion. According to the findings, renal excretion is the main route for the removal of etoricoxib metabolites. Etoricoxib is thoroughly metabolized and excreted mostly in the urine, with just around $1 \%$ of the oral dose recovered intact $[8,9]$. 


\subsection{Pharmacodynamic}

Clinically, there are two categories traditional or non-selective and selective. In the non-selective method, it inhibits both COX-1 and COX-2 isoforms. PG synthesis is mediated by the COX enzyme. COX enzymes take part in the inflammation and enhance the physiological process like cytoprotection, renal hemodynamic, renin synthesis, etc [10,11]. For anti-inflammatory response inhibition of COX-2 is necessary. Etoricoxib is majorly characterized for the COX-2 selectivity [12]. In the non-selective method, their transcription factor and gets deactivated by the kappa B. Cyclic adenosine monophosphate response which is dose dependant and inhibited by etoricoxib [13].

Application: Etoricoxib is applied in the pain which is associated with RA, ankylosing spondylitis, and osteoarthritis also in cardiovascular, gastrointestinal, renal diseases. Etoricoxib has also many applications like it is applied in the treatment of acute gouty arthritis, lower back pain, and postoperative pain.

\subsection{Approved dosage forms of Etoricoxib}

The available medicines in the market al.ong with the brand name and manufacturer are presented in Table $1[14,15]$.

Table 1: Etoricoxib dosage forms along with brand names

\begin{tabular}{llll}
\hline Sr. no & Brand Name & Manufacturer & Dosage form \\
\hline 1. & Coxet $(60 / 90 \mathrm{mg})$ & Anthus pharmaceutical pvt ltd & Tablet \\
2. & Coxifact $(60 / 90 \mathrm{mg})$ & Medico Healthcare & Tablet \\
3. & Coxnuro $(60 / 90 / 120 \mathrm{mg})$ & Emenox Healthcare & Film coated tablet \\
4. & Ebov $(60 / 90 / 120 \mathrm{mg})$ & Glenmark Pharmaceutical Ltd & Film coated tablet \\
5. & Ecoxib $(90 / 120 \mathrm{mg})$ & Anglo French drug \& industries Ltd & Tablet \\
& Eloxib $(90 / 120 \mathrm{mg})$ & Emcure pharmaceuticals Ltd & Tablet \\
6. & Erofica $(90 / 120 \mathrm{mg})$ & Micro labs Ltd & Tablet \\
7. & Nucoxia $(90 / 120 \mathrm{mg})$ & ZydusCadila & Tablet \\
8. & Retoz & Dr. Reddy's Laboratories ltd & Tablet \\
10. & Raviza-TH & Wells Biosciences & Tablet \\
& Thiocolchicoside & & \\
& Etoricoxib $(4 \mathrm{mg}+60 \mathrm{mg})$ FC & & \\
& Tablets & & \\
\hline
\end{tabular}

\section{Need of Analytical and Bioanalytical Methods}

Analytical techniques are very much important for the determination of the compositions by using advanced analytical instruments. By which we can get both qualitative as well as quantitative results. In these methods, instruments used in analysis play a very important role by which high quality and reliable analytical data can get. These methods may be spectral, electrochemical, chromatographic, hyphenated, or miscellaneous. Analytical method creation aids in the understanding of important process parameters and the reduction of their effect on precision and accuracy. Analytical methods should be formulated using the proper methods and analytical requirements outlined in the guidelines of ICH when adhering to GMP and GLP guidelines. Q2: (R1). The analytical approach refers to the task of choosing an accurate assay technique to determine the composition of a formulation which is known as the analytical method [16-19]. The selection of analytical instrumentation and its method in the creation of a fresh analytical technique must rely on the analytical methods and their scope. Specificity, linearity, limits of detection (LOD) and 
quantitation limits (LOQ), range, accuracy, and precision are all essential parameters to consider when developing a process.

Bioanalytical methods aim to quantify a drug \& metabolite of a drug or its biomarker concentration in biological fluids example, blood, plasma, serum, urine, and saliva, as well as tissue extracts. The bioanalytical approach must meet stringent method validation requirements set out by regulatory bodies like the US Food and Drug Administration (USFDA) the European Medicines Agency (EMA). It is essential for the development of accurate and very efficient methods for performing both qualitative and quantitative analysis, as well as cost-effective methodologies and shorter analysis times. It is essential to develop reliable and efficient procedures for performing both analysis including quality and quantity measurement, as well as methodologies that should be cheap and shorter analysis times [20]. The purpose of doing analytical method validation and its creation arose as a result of international competition, the need to maintain quality standards of high commercial and consumer value, and ethics of the consumer should be considered. Regulatory bodies have established the standard and procedure for granting approval, authentication, and registration following the reference. Method creation is a time-consuming, costly, and complex process. The steps and procedures used to conduct an analysis are detailed in an analytical process. Sample preparation, its standard solutions, and reagents; application of apparatus; calibration curve generation; application of measurement formulae, and so on. The cycle of the analytical method is shown in figure 2 .

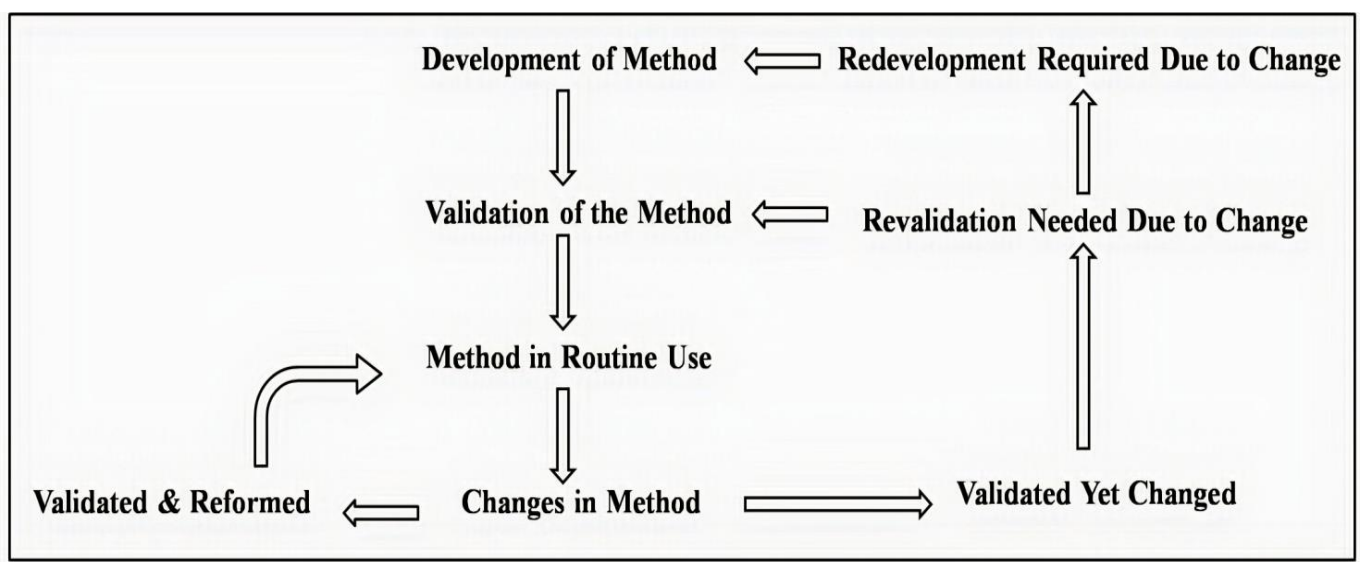

Figure 2: Analytical method development and its cycle

\section{Analytical Method Development By UV Spectrophotometer}

Shahi et al. developed the method UV spectrophotometrically for analysis of Etoricoxib in bulk as well tablet dosage form. Where, Dissolution studies are performed on all immediate-release tablets in $\mathrm{HCl} 0.1$ $\mathrm{N}$, with the guidance of by SUPAC-IR, or in a specific medium used for dissolution, which is stated in the monograph officially. The UV instrumental system, which was produced in HCL $0.1 \mathrm{~N}$ and is applicable for analyzing IR tablets, is quick, precise, detailed, and highly sensitive. The process has been shown to accurately determine Etoricoxib in different dosage forms as well as in bulk. The maximum absorption of etoricoxib in $0.1 \mathrm{~N} \mathrm{HCl}$ was measured at $233 \mathrm{~nm}$. In the concentration range of $2-24 \mathrm{~g} / \mathrm{ml}$, Beer-law Lambert's was followed. The study was suggested that the process is free from impurities and also other additives were absent when calculating drug concentration in the formulation [21]. Bharatheeshaet al. developed a reliable and sensitive extractive spectrophotometric determination of Etoricoxib in different dosage forms. Two methods were developed, method A and method B which consist of the extract of chloroform and a combination of the drug with bromocresol purple and bromothymol blue. The details for the use of instrument model, solvent and wavelength used have been mentioned in Table 2 [22]. Jat RK et al. studied the spectrophotometric quantification of the Etoricoxib tablet and bulk using a hydrotropic agent. The use of the hydrotropic solubilization technique increases the aqueous solubility of poorly watersoluble drugs. Summary of the instrument, solvent and wavelength has been mentioned in Table 2 [23]. 
Singh S et al. developed and validated simple and low-cost ultraviolet spectrophotometric methods [24]. Shakya AK et al. developed UV as well as HPLC methods for the estimation of the etoricoxib in different dosage forms [25]. Shah et al. studied and done the literature survey to gather the information of different analytical methods for the recently approved fixed-dose combination of drugs i.e. Pregabalin (PGB) and Etoricoxib (ETC). Various methods have been reported like HPLC, spectroscopy, HPTLC, hyphenated techniques\& thin layer chromatography [26]. Many researchers develop the method by using a UV spectrophotometer. Some of the examples have been mentioned in Table 2 [27-30].

Table 2: Analytical method development using UV spectrophotometer

\begin{tabular}{|c|c|c|c|c|c|}
\hline $\begin{array}{l}\mathrm{Sr} \\
\text { no }\end{array}$ & $\begin{array}{l}\text { Sample/dosage } \\
\text { form }\end{array}$ & $\begin{array}{l}\text { Method/Instrument } \\
\text { model }\end{array}$ & Solvent/solution & Wavelength & Reference \\
\hline 1 & $\begin{array}{l}\text { Bulk and IR } \\
\text { tablet }\end{array}$ & Shimadzu UV 1700 & $0.1 \mathrm{~N} \mathrm{HCl}$ & $233 \mathrm{~nm}$ & 21 \\
\hline 2 & Bulk and tablet & $\begin{array}{l}\text { Shimadzu } 1700 \text { UV- } \\
\text { Visible } \\
\text { spectrophotometer }\end{array}$ & Methanol & $407 \& 416 \mathrm{~nm}$ & 2 \\
\hline 3 & Bulk and tablet & $\begin{array}{l}\text { Systronic } 2101 \text { UV- } \\
\text { Visible } \\
\text { spectrophotometer }\end{array}$ & $\begin{array}{l}2 \mathrm{M} \text { Sodium } \\
\text { Benzoate solution }\end{array}$ & $282 \mathrm{~nm}$ & 23 \\
\hline 4 & Tablet & $\begin{array}{l}\text { Shimadzu } 1800 \text { UV- } \\
\text { Visible } \\
\text { spectrophotometer }\end{array}$ & $0.1 \mathrm{M} \mathrm{HCl}$ & $233 \mathrm{~nm}$ & 24 \\
\hline 5 & Tablet & $\begin{array}{l}\text { V570 UV-Visible } \\
\text { spectrophotometer }\end{array}$ & Methanol & $284 \mathrm{~nm}$ & 25 \\
\hline 6 & Bulk and tablet & $\begin{array}{l}\text { UV-Visible } \\
\text { spectrophotometer }\end{array}$ & $0.1 \mathrm{M} \mathrm{NaOH}$ & $284 \mathrm{~nm}$ & 26 \\
\hline 7 & Tablet & $\begin{array}{l}\text { UV-Visible } \\
\text { spectrophotometer } \\
\text { Shimadzu } 1800\end{array}$ & $\begin{array}{l}0.1 \mathrm{~N} \mathrm{HCl} \\
\text { solution for } \\
\text { Method } 1 \\
\mathrm{NaCH} 3 \mathrm{COO} \\
\text { buffer of } \mathrm{pH} 7 \\
\text { for method } 2 \text { and } \\
\text { phosphate buffer } \\
\text { pH for method } 3\end{array}$ & $\begin{array}{l}\text { Method1 }=234 \\
\text { method2 }=225.6 \\
\text { method3 }=234.4\end{array}$ & 27 \\
\hline 8 & Tablet & $\begin{array}{l}\text { UV-Visible } \\
\text { spectrophotometer } \\
\text { Shimadzu } 1800\end{array}$ & Methanol & 248 & 28 \\
\hline 9 & Tablet & $\begin{array}{l}\text { UV-Visible } \\
\text { spectrophotometer } \\
\text { Shimadzu } 1800\end{array}$ & Methanol & 235 & 29 \\
\hline
\end{tabular}

\section{Analytical method development by HPLC}

Thimmaraju et al. developed a very simple, accurate and reliable reverse phase HPLC method and also validation was done for the estimation of etoricoxib in various pharmaceutical dosage forms. The excipients in tablet dosage forms were found to not affect the quantification of active drugs using the proposed process. Reverse-phase chromatography was used on a Shimadzu HPLC with a detector of 10 AT and a C18 Column 250 X $4.6 \mathrm{~mm}$ of ODShypersiland a flow pump with constant flow. Acetonitrile: $(0.05 \mathrm{M})$ $\mathrm{KH} 2 \mathrm{PO} 4$ buffer (50:50) used as a mobile phase. The detection was monitored at $283 \mathrm{~nm}$. Interday and 
intraday precision were calculated and were observed in an acceptable range. The method which is used by RP-HPLC is sensitive, reproducible, and specific for the estimation of etoricoxib in various pharmaceutical dosage forms [31]. Haque et al. developed the method for the estimation of etoricoxib by the reverse phase HPLC method in pharmaceutical drugs where the chromatographic determination is determined on the C18 column. The details for the method have been summarised in Table 3 [32-36].

Table 3: Analytical method development using HPLC method

\begin{tabular}{|c|c|c|c|c|c|c|c|}
\hline $\begin{array}{l}\text { Sr } \\
\mathbf{N} \\
\mathbf{o}\end{array}$ & Sample & $\begin{array}{l}\text { Stationary } \\
\text { phase/colu } \\
\text { mn }\end{array}$ & Mobile phase & $\begin{array}{l}\text { Wavelength } \\
\text { (nm) }\end{array}$ & $\begin{array}{l}\text { Flow rate } \\
(\mathrm{ml} / \mathrm{min})\end{array}$ & RT(min) & Reference \\
\hline 1 & $\begin{array}{l}\text { Tablet } \\
\& \text { bulk }\end{array}$ & $\begin{array}{l}\text { ODS C-18 } \\
250 \times 4.6 \\
\text { mm,Hypersil }\end{array}$ & $\begin{array}{l}\text { acetonitrile: } \\
(0.05 \mathrm{M}) \\
\text { Potassium } \\
\text { dihydrogen } \\
\text { phosphate buffer } \\
(50: 50)\end{array}$ & 283 & 1.8 & 3.083 & 31 \\
\hline 2 & Tablet & $\begin{array}{l}\text { C18 column } \\
(250 \times 4.6 \\
\text { mm. } 5 \mu \mathrm{m}\end{array}$ & $\begin{array}{l}\text { acetonitrile: } \\
\text { Ammonium } \\
\text { Acetate buffer }\end{array}$ & 235 & 1 & 5.337 & 32 \\
\hline 3 & Tablet & $\begin{array}{l}\text { ODS } \\
\text { Hypersil C- } \\
18(250 \times 4.6 \\
\mathrm{mm} ., 5 \mu \mathrm{m})\end{array}$ & $\begin{array}{l}\text { acetonitrile and } \\
\text { potassium } \\
\text { dihydrogen } \\
\text { phosphate buffer } \\
(\mathrm{pH} 4.2)(46: 54 \\
\% \mathrm{v} / \mathrm{v})\end{array}$ & 280 & 1.2 & 3.083 & 33 \\
\hline 4 & Tablet & $\begin{array}{l}\text { (ODS) } \\
\text { octadecylsilan } \\
\text { e C18 }\end{array}$ & $\begin{array}{l}\text { Methanol } \\
\text { \&phoshpahte } \\
\text { buffer } \mathrm{pH} 6 \\
(70: 30) \mathrm{v} / \mathrm{v}\end{array}$ & 215 & 0.8 & 5.98 & 34 \\
\hline 5 & $\begin{array}{l}\text { Tablet } \\
\text { and bulk }\end{array}$ & $\begin{array}{l}\text { ODS } \\
\text { Hypersil } 2 \\
\text { C18 (size } \\
4.6 \mathrm{mmx} 250 \mathrm{~m} \\
\mathrm{~m}, \text { particle } \\
\text { size } 5 \mu \mathrm{m}\end{array}$ & Methanol & 233 & 1 & 3.28 & 35 \\
\hline 6 & $\begin{array}{l}\text { FDC } \\
\text { tablet } \\
\text { (Etorico } \\
\text { xib }+ \\
\text { Thiocol } \\
\text { chicosid } \\
\text { e) }\end{array}$ & $\begin{array}{l}\text { lichrosphere } \\
\text { RP-select B } \\
\text { column } \\
(250 \times 4.6 \mathrm{~mm}) \\
\text { partical size } 5 \\
\mu \mathrm{m}\end{array}$ & $\begin{array}{l}1 \mathrm{ml} \text { TFA in } 2 \\
\text { litermilli-Q } \\
\text { water: } \\
\text { Acetonitrile } \\
(75: 25 \mathrm{v} / \mathrm{v})\end{array}$ & 258 & 1.5 & $\begin{array}{l}\text { Etoricoxib } \\
=8.62 \\
\text { Thiocolch } \\
\text { icoside }= \\
3.37\end{array}$ & 36 \\
\hline 7 & Tablet & $\begin{array}{l}\text { ODS } \\
\text { Hypersil C18 } \\
\text { (size } \\
4.6 \mathrm{mmx} 200 \mathrm{~m} \\
\mathrm{~m}, \text { particle } \\
\text { size } 5 \mu \mathrm{m}\end{array}$ & $\begin{array}{l}\text { Methanol \& } \\
\text { Phosphate buffer } \\
\text { pH } 6(70: 30 \mathrm{v} / \mathrm{v})\end{array}$ & 215 & 0.8 & 5.98 & 37 \\
\hline
\end{tabular}




\section{Analytical Method Development Using HPTLC Method}

Shah NJ et al. studied and developed a suitable, sensitive validation method by using the HPTLC method for the analysis of etoricoxib and Dhaneshwar SR et al. developed the method by HPTLC techniques for the determination of etoricoxib and paracetamol which is summarised in table $4[38,39]$.

Table 4: Analytical method development using HPTLC method

\begin{tabular}{lllllll}
\hline $\begin{array}{l}\text { Sr } \\
\text { No }\end{array}$ & Method & Sample & $\begin{array}{l}\text { Stationary } \\
\text { phase/column }\end{array}$ & Mobile phase & $\begin{array}{l}\text { Wavelength } \\
\text { (nm) }\end{array}$ & Reference \\
\hline $\mathbf{1}$ & HPTLC & Bulk & $\begin{array}{l}\text { Silica gel pre- } \\
\text { coated 60F254 }\end{array}$ & $\begin{array}{l}\text { Chloroform:metha } \\
\text { nol:toluene }(4: 2: 4 \\
\text { v/v/v) }\end{array}$ & 38 \\
2. & HPTLC & $\begin{array}{l}\text { Bulk and } \\
\text { tablet }\end{array}$ & $\begin{array}{l}\text { Aluminium plates } \\
\text { coated with silica }\end{array}$ & $\begin{array}{l}\text { Methanol:toluene:e } \\
\text { thyl acetate }(1: 6: 4 \\
\text { v/v/v) }\end{array}$ & 39 \\
\hline
\end{tabular}

\section{Bioanalytical Method Development}

Ramakrishna NV et al. studied the liquid chromatographic method by using ultraviolet spectroscopy for the analysis of etoricoxib in plasma obtained from humans by using liquid-liquid extraction. SPE means solidphase extraction and HPLC with photochemical cyclization and fluorescence detector was used for the detection purpose along with a structural counterpart as internal standards are employed to quantify drugs from urine and plasma collected from humans. Matthews et al. determined the limit of quantification and it was $5 \mathrm{ng} / \mathrm{ml}$. Rose et al.. identified a liquid chromatography/tandem mass spectrometry (LC-MS/MS) method for determining Etoricoxib in human plasma using atmospheric pressure chemical ionization (APCI). Brum Junior L et al. studied and developed the LC-Tandem mass spectroscopy method and its validation for the analysis of drugs in plasma collected from the human body and in the pharmaceutical dosage form. Werner $\mathrm{U}$ et al. studied the method development for the combination of the drug etoricoxib and valdecoxib from the plasma collected from the human body. The method developed was LCMS. In this study, researches had connected the RP-HPLC method with mass spectroscopy. Many researchers have made efforts for the development of the bioanalytical method for etoricoxib. Some of the examples have summarized in Table 5 [41-45].

Table 5: Bioanalytical method development using various methods

\begin{tabular}{|c|c|c|c|c|c|c|c|c|}
\hline $\begin{array}{l}\mathrm{Sr} \\
\mathrm{N} \\
\mathrm{o}\end{array}$ & $\begin{array}{l}\text { Metho } \\
\text { d }\end{array}$ & $\begin{array}{l}\text { Sample/ } \\
\text { dosage } \\
\text { form }\end{array}$ & $\begin{array}{l}\text { Stationary } \\
\text { phase/column }\end{array}$ & Mobile phase & $\begin{array}{l}\text { Wavele } \\
\text { ngth } \\
(\mathrm{nm})\end{array}$ & $\begin{array}{l}\text { Flow } \\
\text { rate } \\
\text { min/ } \\
\mathrm{ml}\end{array}$ & $\begin{array}{l}\text { Retent } \\
\text { ion } \\
\text { time } \\
\text { (min) }\end{array}$ & Reference \\
\hline 1 & $\begin{array}{l}\text { HPLC- } \\
\text { UV }\end{array}$ & $\begin{array}{l}\text { Human } \\
\text { plasma }\end{array}$ & $\begin{array}{l}\text { C18 column, } \\
\text { waters symmetry, } \\
(5 \mu \mathrm{m}, 250 \times 4.6 \\
\mathrm{mm})\end{array}$ & $\begin{array}{l}\text { Water: } \\
\text { acetonitrile } \\
(58: 42 \mathrm{v} / \mathrm{v})\end{array}$ & 284 & 1.2 & 7.8 & 41 \\
\hline 2. & $\begin{array}{l}\text { LC- } \\
\text { MS/MS }\end{array}$ & $\begin{array}{l}\text { Tablet, } \\
\text { human } \\
\text { plasma }\end{array}$ & $\begin{array}{l}\text { Column of C18, } \\
\text { Phenomenex } \\
\text { Luna }(50 \mathrm{~mm} \mathrm{x} \\
3.0 \mathrm{~mm}, 3 \mu \mathrm{m})\end{array}$ & $\begin{array}{l}\text { Water: } \\
\text { acetonitrile } \\
(5: 95 \mathrm{v} / \mathrm{v}) \& 1 \\
\% \text { acetic acid }\end{array}$ & - & - & 0.79 & 42 \\
\hline
\end{tabular}


A Review on Various Analytical Methodologies for Etoricoxib

\begin{tabular}{|c|c|c|c|c|c|c|c|c|}
\hline 3 & $\begin{array}{l}\mathrm{LC}- \\
\mathrm{APCI} / \\
\mathrm{MS} / \mathrm{MS}\end{array}$ & $\begin{array}{l}\text { Human } \\
\text { plasma }\end{array}$ & $\begin{array}{l}\text { C18, } \\
\text { Phenomenex } \\
\text { Luna }(50 \mathrm{~mm} x \\
3.0 \mathrm{~mm}, 3 \mu \mathrm{m})\end{array}$ & $\begin{array}{l}\text { Water: } \\
\text { acetonitrile } \\
(5: 95 \mathrm{v} / \mathrm{v}) \& 1 \\
\% \text { acetic acid }\end{array}$ & - & - & 0.75 & 43 \\
\hline 4 & $\begin{array}{l}\text { HPLC- } \\
\text { MS/MS }\end{array}$ & $\begin{array}{l}\text { Human } \\
\text { plasma }\end{array}$ & $\begin{array}{l}\text { Hypersil, C8 } \\
(50 \mathrm{~mm} \times 3.0 \mathrm{~mm} \text {, } \\
3 \mu \mathrm{m})\end{array}$ & $\begin{array}{l}\text { Acitonitrile } \\
\text { and } \\
\text { ammonium } \\
\text { ethanoate } \\
(35: 65 \mathrm{v} / \mathrm{v})\end{array}$ & - & - & 2.1 & 44 \\
\hline 5 & $\begin{array}{l}\text { LC- } \\
\text { MS/MS }\end{array}$ & $\begin{array}{l}\text { Rat } \\
\text { plasma }\end{array}$ & $\begin{array}{l}\text { Waters } \\
\text { ACQUITY } \\
\text { UPLC BEH } \\
\mathrm{C}_{18} \text { column } \\
(2.1 \times 50 \mathrm{~mm}, 1.7 \\
\mu \mathrm{m} \text { particle size }\end{array}$ & $\begin{array}{l}\text { Ammonium } \\
\text { acetate buffer } \\
\text { pH } 9.2 \text { \& } \\
\text { Methanol } \\
(30: 70 \mathrm{v} / \mathrm{v})\end{array}$ & - & 0.2 & 1.1 & 45 \\
\hline
\end{tabular}

\section{Conclusion}

This review has been emphasized mainly on the different analytical and bioanalytical methods used for the estimation of the etoricoxib in various medicinal drugs as well as in the bulk form of the drugs. Different dosage forms are containing a combination of etoricoxib. The researchers have made their efforts for the development of analytical and bioanalytical methods which include, UV spectrophotometry, LC, HPLC, HPTLC, RP-HPLC, TLC and also other hyphenated methods. Hyphenated techniques include LCMS/MS, HPLC-MS/MS, LC-APCI/MS/MS, etc. all the analytical methods developed are very sensitive, reliable, reproducible, precise and having a higher level of automation and sample throughput. The literature survey is done to collect the information of different analytical instrumental methods. Such data would get beneficial to develop a novel analytical method.

\section{Competing Interests}

Authors report no conflict of interest concerning this review article.

\section{How to Cite this Article:}

M. Prajapati, D. B. Yamgar, M. N. Desale, and B. Fegade, "A Review on Various Analytical Methodologies for Etoricoxib”, Adv. J. Grad. Res., vol. 11, no. 1, pp. 61-70, Dec. 2021.

\section{References}

[1] A. Escudero-Contreras, J. V. M. Cervantes, \& E. Collantes-Estevez., Update on the clinical pharmacology of etoricoxib, a potent cyclooxygenase-2 inhibitor. International Journal of Clinical Rheumatology, Vol. 2 Issue. 6, pp.545, 2007.

[2] P. Brooks, \& P. Kubler., Etoricoxib for arthritis and pain management. Therapeutics and clinical risk management, Vol. 2 Issue. 1 , pp. $45,2006$.

[3] D. Riendeau, M. D. Percival, C. Brideau, S. Charleson, D. Dube, D. Ethier, \& C. C Chan., Etoricoxib (MK-0663): preclinical profile and comparison with other agents that selectively inhibit cyclooxygenase-2. Journal of Pharmacology and Experimental Therapeutics, Vol. 296, Issue. 2, pp.558-566, 2001.

[4] M. Ouellet, D. Riendeau, \& M. D. Percival., A high level of cyclooxygenase-2 inhibitor selectivity is associated with a reduced interference of platelet cyclooxygenase-1 inactivation by aspirin. Proceedings of the National Academy of Sciences Vol. 98, Issue. 25, pp.14583-14588, 2001.

[5] S. R. Shahi, G. R. Agrawal, P. B. Rathi, N. V. Shinde, V. G. Somani, S. B. Mahamuni \& A. N. Padalkar., Development and validation of UV spectrophotometric method for the determination of etoricoxib in bulk and tablet formulation. Rasayan J Chem, Vol. 1, Issue. 2, pp.296390-394, 2008.

[6] J. K. Takemoto, J. K. Reynolds, C. M. Remsberg, K. R. Vega-Villa \& N. M. Davies., Clinical pharmacokinetic and pharmacodynamic profile of etoricoxib. Clinical pharmacokinetics, Vol. 11, No. 47, pp.296703-720, 2008.

[7] K. Kassahun, I. S. McIntosh, M. Shou, D. J. Walsh, C. Rodeheffer, D. E. Slaughter, \& A. D. Rodrigues., Role of human liver cytochrome P4503A in the metabolism of etoricoxib, a novel cyclooxygenase-2 selective inhibitor. Drug metabolism and disposition, Vol. 29, Issue. 6, pp.2813-820, 2001. 
[8] N. G. Agrawal, A. G. Porras, C. Z. Matthews, M. J. Rose, E. J. Woolf, B. J. Musser \& K. M. Gottesdiener., Single-and multiple-dose pharmacokinetics of etoricoxib, a selective inhibitor of cyclooxygenase-2, in man. The Journal of Clinical Pharmacology, Vol. 43, Issue. 3, pp.268-276, 2003.

[9] A. D. Rodrigues, R. A. Halpin, L. A. Geer, D. Cui, E. J. Woolf, C. Z. Matthews \& N. G Agrawal., Absorption, metabolism, and excretion of etoricoxib, a potent and selective cyclooxygenase-2 inhibitor, in healthy male volunteers. Drug metabolism and disposition, Vol. 31, Issue. 2, pp.224-232, 2003.

[10] Y. Yuan \& R. H. Hunt., Global gastrointestinal safety profile of etoricoxib and lumiracoxib. Current pharmaceutical design, Vol. 13, Issue. 22, pp.2237-2247, 2007.

[11] J. J. Deeks, L. A. Smith \& M. D. Bradley., Efficacy, tolerability, and upper gastrointestinal safety of celecoxib for treatment of osteoarthritis and rheumatoid arthritis: systematic review of randomised controlled trials. Bmj, Vol. 325, Issue. 7369, pp.619, 2002.

[12] A. Dallob, C. J. Hawkey, H. Greenberg, N. Wight, P. De Schepper, S. Waldman \& K. Gottesdiener., Characterization of etoricoxib, a novel, selective COX-2 inhibitor. The Journal of Clinical Pharmacology, Vol. 43, Issue. 6, pp.573-585, 2003.

[13] E. Niederberger, C. Manderscheid \& G. Geisslinger., Different COX-independent effects of the COX-2 inhibitors etoricoxib and lumiracoxib. Biochemical and biophysical research communications, Vol. 342, Issue. 3, pp.940-948, 2006.

[14] "List of marketed formulation \& dose streangth of etoricoxib." https://www.ema.europa.eu/en/documents/referral/arcoxia-article-612-referral-annex-i-ii-iii-iv_en.pdf (Accessed Oct 23, 2021)

[15] "Maximum dose strength of etoricoxib." https://assets.publishing.service.gov.uk/government/uploads/system/uploads/attachment_data/file/560584/October_Drug_Safety_U pdate.pdf (Accessed Oct 23, 2021)

[16] A. Chauhan, B. Mittu \& P. Chauhan., Analytical method development and validation: a concise review. J Anal Bioanal Tech, Vol. 6, Issue. 1, pp.1-5, 2015.

[17] International Conference on Harmonization (ICH) of Technical Requirements for Registration of Pharmaceuticals for Human Use, Topic Q7: Good Manufacturing Practices for Pharmaceutical Ingredients, 2000.

[18] Current Good Manufacturing Practices for finished Pharmaceuticals, 21 CFR, Parts 210 and 211, US Food and Drug Administration.

[19] RD. McDowall., Effective and practical risk management options for computerised system validation. The Quality Assurance Journal: The Quality Assurance Journal for Pharmaceutical, Health and Environmental Professionals. Vol. 9, Issue. 3, pp.196-227. 2005.

[20] L. Nováková, P. Svoboda \& J. Pavlík., Ultra-high performance liquid chromatography. In Liquid Chromatography pp. 719-769, 2017.

[21] S. R. Shahi, G. R. Agrawal, P. B. Rathi, N. V. Shinde, V. G. Somani, S. B. Mahamuni, \& A. N. Padalkar., Development and validation of UV spectrophotometric method for the determination of etoricoxib in bulk and tablet formulation. Rasayan J Chem, Vol. 1, Issue. 2, pp.390-394, 2008

[22] J. Shah \& R. Kotadiya., A Critical Review on Analytical Methods for Recently Approved FDC Drugs: Pregabalin and Etoricoxib. Critical Reviews in Analytical Chemistry, pp.1-21, 2020.

[23] R. K. Jat, R. C. Chhipa \& S. Sharma., Spectrophotometric quantification of Etoricoxib in bulk drug and tablets using hydrotropic agent. Phramacore, Vol. 1, Issue. 2, pp.96-102, 2010.

[24] S. Singh, A. Mishra, A. Verma, A. K. Ghosh \& A. K Mishra., A simple Ultraviolet spectrophotometric method for the determination of etoricoxib in dosage formulations. Journal of advanced pharmaceutical technology \& research, Vol. 3, Issue. 4, pp.237, 2012.

[25] A. K. Shakya \& N. A. Khalaf., High Performance Liquid Chromatographic and Ultra Violet Spectroscopic Determination of Etoricoxib in Pharmaceutical Formulations. Asian Journal of Chemistry, Vol. 19, Issue. 3, pp.2059, 2007.

[26] B. N. Suhagia, H. M. Patel, S. A. Shah, I. S. Rathod \& B. P. Marolia., spectrophotometric estimation of Etoricoxib in bulk drug and dosage forms. Indian journal of pharmaceutical sciences, Vol. 67, Issue. 5, pp.634, 2005.

[27] P. B. Purneshwar., New Spectrophotometric Methods for the Assay of Etoricoxib. Asian Journal of Pharmaceutics (AJP): Vol. 12, Issue. 2, pp. 1-5, 2018.

[28] A. B. Patel, E. Vaghasiya, A. J. Vyas, A. I. Patel \& N. K. Patel., Spectrophotometric first order derivative method for simultaneous determination of etoricoxib and paracetamol in tablet dosage form. Journal of Medicinal and Chemical Sciences, Vol. 3, Issue. 3, pp.300-307, 2020 .

[29] G. Manideep, N.L.J. Shane, G. Pai, and M.B. Sathyanarayana. Development and Validation of a UV Spectroscopic Method to Estimate Etoricoxib in Bulk and Tablet Formulation. Research Journal of pharmacy and Technology, Vol. 11, Issue. 2, pp.758-760, 2018 .

[30] J. Shah \& R. Kotadiya., A Critical Review on Analytical Methods for Recently Approved FDC Drugs: Pregabalin and Etoricoxib. Critical Reviews in Analytical Chemistry, pp.1-21, 2020.

[31] M. K. Thimmaraju, V. Rao \& S. Gurrala., RP HPLC method for the determination of finasteride and tamsulosin in bulk and pharmaceutical formulations. Der Pharmacia Lettre, Vol. 3, Issue. 5, pp.79-86, 2011.

[32] M. Haque, S. Nasrin, M. M. Monir, M. M. Rahman \& S. Chowdhury., Method development and validation of RP-HPLC method of etoricoxib in bulk and its tablet dosage forms. American Journal of PharmTech Research, Vol. 2, Issue. 6, pp.275-283, 2012.

[33] S. Topalli, T. G. Chandrashekhar \& M. M. Annapurna., Validated RP-HPLC method for the assay of etoricoxib (a non-steroidal antiinflammatory drug) in pharmaceutical dosage forms. E-Journal of chemistry, Vol. 9, Issue. 2, pp.832-838, 2012.

[34] M. Alzweiri. M. Sallam, W. Al-Zyoud \& K. Aiedeh., Stability Study of Etoricoxib a Selective Cyclooxygenase-2 Inhibitor by a New Single and Rapid Reversed Phase HPLC Method. Symmetry, Vol. 10, Issue. 7, pp.288, 2018.

[35] P. S. Gangane, S. M. Bagde, S. G. Mujbaile, K. D. Niranjane \& P. S. Gangane., Development and Validation of HPLC Assay Method for Etoricoxib in Bulk Drug and Tablet Formulation. International Journal of Natural Sciences, Vol. 4, Issue. 24, pp-1565-1625, 2014.

[36] D. S. Rajan, A. Bose, K. V. Gowda, A. Ghosh \& T. K. Pal., Development and validation of an HPLC method for analysis of etoricoxib in human plasma. Indian journal of pharmaceutical sciences, Vol. 68, Issue. 4, pp.1-3, 2006.

[37] M. Alzweiri, M. Sallam, W. Al-Zyoud and K. Aiedeh. Stability Study of Etoricoxib a Selective Cyclooxygenase-2 Inhibitor by a New Single and Rapid Reversed Phase HPLC Method. Symmetry, Vol. 10, Issue. 7, p.288, 2018. 
[38] N. J. Shah, S. J. Shah, D. M. Patel \& N. M. Patel., Development and validation of HPTLC method for the estimation of etoricoxib. Indian journal of pharmaceutical sciences, Vol. 68, Issue. 6, pp.788, 2006.

[39] S. R. Dhaneshwar, K. O. Raut \& V. K. Bhusari., Validated HPTLC Method for Simultaneous Estimation of Paracetamol and Etoricoxib in Bulk Drug and Formulation. Asian Journal of Pharmaceutical \& Biological Research (AJPBR), Vol. 1, Issue. 2, 2011.

[40] N. V. S. Ramakrishna, K. N. Vishwottam, S. Wishu \& M. Koteshwara., Validated liquid chromatographic ultraviolet method for the quantitation of etoricoxib in human plasma using liquid-liquid extraction. Journal of Chromatography B, Vol. 816, Issue. 2, pp.215$221,2005$.

[41] L. Brum Junior, D. Cátia Ceni, M. Fronza, P. Renato de Oliveira \& S. Luiz Dalmora., Validation of an LC-tandem MS/MS method for the determination of etoricoxib in human plasma and pharmaceutical formulations. Journal of liquid chromatography \& related technologies, Vol. 29, Issue. 1, pp.123-135, 2006.

[42] S. L. Dalmora, L. Brum Junior, R. M. Ferretto, P. R. D. Oliveira, T. Barth \& M. D. S. Sangoi., Determination of etoricoxib in human plasma using automated on-line solid-phase extraction coupled with LC-APCI/MS/MS. Química Nova, Vol. 31, Issue. 3, pp.574-578, 2008.

[43] M. J. Rose, N. Agrawal, E. J. Woolf \& B. K. Matuszewski., Simultaneous determination of unlabeled and carbon-13-labeled etoricoxib, a new cyclooxygenase-2 inhibitor, in human plasma using HPLC-MS/MS. Journal of pharmaceutical sciences, Vol. 91, Issue. 2, pp.405-416, 2002.

[44] U. Werner, D. Werner, B. Hinz, C. Lambrecht \& K Brune., A liquid chromatography-mass spectrometry method for the quantification of both etoricoxib and valdecoxib in human plasma. Biomedical Chromatography, Vol. 19, Issue. 2, pp.113-118, 2005.

[45] W.D. Eure, R.G. Grossman, P.J. Horner and D.S.L. Chow. LC-MS/MS assay of riluzole and etoricoxib in rat plasma and brain tissue with applications for sampling and evaluation in pre-clinical rat model of traumatic brain injury. Talanta Open, 4, p.100052, 2021.

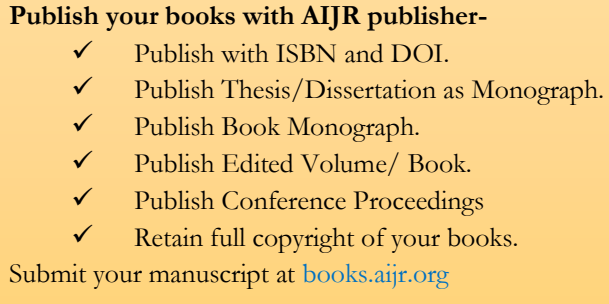

Publish your research article in AIJR journals-

$\checkmark \quad$ Online Submission and Tracking

$\checkmark$ Peer-Reviewed

$\checkmark$ Rapid decision

$\checkmark$ Immediate Publication after acceptance

$\checkmark$ Articles freely available online

$\checkmark \quad$ Retain full copyright of your article.

Submit your article at journals.aijr.org 